\title{
Quay wall stability and strength evaluation
}

\author{
V. Paulauskas*, D. Paulauskas**, B. Placiene ${ }^{* * *}$, R. Barzdziukas $* * * *$ \\ *Klaipeda University, H. Manto g. 84, LT-92294, Klaipeda, Lithuania, E-mail: vytautaskltc@gmail.com \\ **Klaipeda University, H. Manto g. 84, LT-92294, Klaipeda, Lithuania, E-mail: paulauskasd75@gmail.com \\ ***Klaipeda University, H. Manto g. 84, LT-92294, Klaipeda, Lithuania, E-mail: birute.placiene@gmail.com \\ ****Klaipeda University, H. Manto g. 84, LT-92294, Klaipeda, Lithuania, E-mail: raimondas.barzdziukas@ku.lt \\ cross $^{\text {ref }}$ http://dx.doi.org/10.5755/j01.mech.23.2.13776
}

\section{Introduction}

Quay wall lifespan depends on the quay wall type, design and construction standard regulations and quality; and safety terms, which were applied during the design, construction and exploitation [1-3]. However, shipping conditions change and new types of the ships, cargo transportation and handling methods and conditions, especially of cargo storage, appear, therefore, the quay wall lifespan in some cases needs to be extended [4].

Investigation methods and standards vary in different countries and it is important to make relevant decisions regarding the extensions of the quay walls exploitation time and updating the conditions $[5,6]$.

Differences in methods and standards regarding quay walls stability and strength evaluation require a comparison between different results, which is very important for the investigation and optimization of quay walls effectiveness. Lifespan of quay walls could be extended on the basis of accurate investigations and quay wall strength and stability calculation but at the same time different standards should be taken into account for different conditions, that is corrosion intensity, ships mooring conditions, current influence, etc. [7, 8].

Accurate and exact investigation methods of the real quay wall situation can assist to safe longer use of quay walls and decrease their maintenance costs and renovation investments. The methodology for the evaluation of the quay wall potential is very important to optimize the exploitation and operation of the existing quay walls and sustaining their workable conditions as long as possible ensuring their safety characteristics $[4,9,10]$.

In this study the northern part of the Klaipeda port, where quay walls (jetties) were constructed more than 50 years ago, is taken as a case study. These quay walls were used very intensively during their exploitation time with just some small renovation adjusting to the increased size of the moored ships.

\section{Ports and port quay wall situation analysis}

Port infrastructure is very expensive and its renovation works or new constructions request a lot of investments. As a result of investment limitations many ports continue exploitation of old waterfront structures, such as quay walls, breakwaters or other waterfront constructions, which are older than defined in regulations for the concrete constructions of a country $[2,3]$.

Block (gravity) type of the quay walls life time usually is more than 100 years and during such a long time a lot of changes take place in shipping conditions: change of cargo, types of the ships and port handling equipment. New shipping conditions request to adopt quay walls to new ship mooring and cargo handling equipment with limit or without changing the quay walls construction $[11,12]$. The average life time of a steel sheet pile quay wall is about 50 years. During the last 50 years maritime transport situation has changed dramatically: increase of container, crude oil and oil production, and bulk cargo transportation quantities and ship size. A lot POST PANAMAX and SUECMAX oil and oil production tankers used during the last years in the East Baltic Sea ports. Many quay walls or jetties in the ports were built for the smaller ships, but today try attracting a lot of bigger ships. Every day in Baltic Sea sail more than 2500 ships [13] and more than 25\% between mentioned numbers of the ships are PANAMAX and bigger oil, oil products tankers, bulk ships and container carriers, which has length up to $300-340 \mathrm{~m}$, width up to $48-52 \mathrm{~m}$, draft up to $15,0-16,0 \mathrm{~m}$.

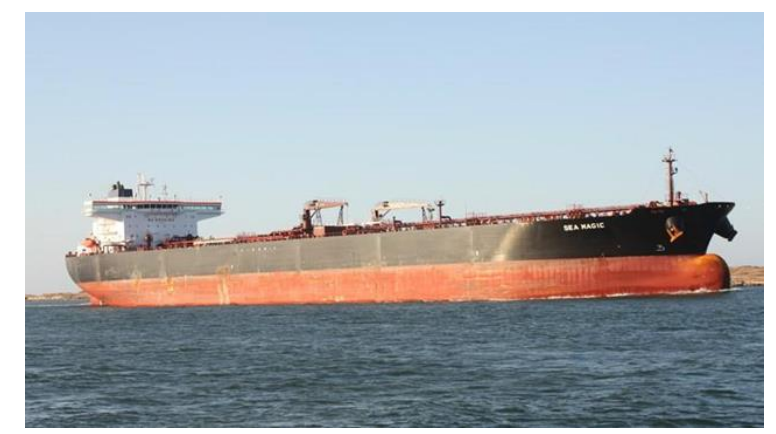

Fig. 1 POST PANAMAX tanker "SEAMAGIC": $L=250 \mathrm{~m}, B=44 \mathrm{~m}, T=14,5 \mathrm{~m}, D W T=115000 \mathrm{t}$

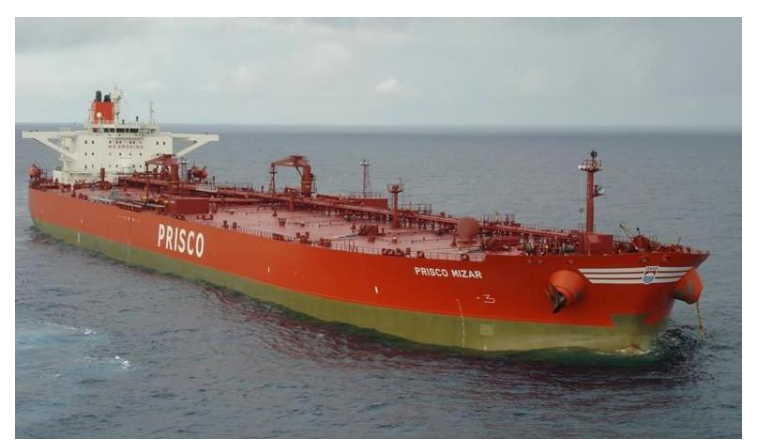

Fig. 2 SUECMAX tanker „PRISCO MIZAR“, $L=289$ m, $B=48 \mathrm{~m}, T=16,0 \mathrm{~m}, D W T=160000 \mathrm{t}$

As example, Klaipeda oil terminal jetties were built in 1965 for the ships which had capacity 
(DWT - deadweight) up to $20000 \mathrm{t}$, later (in 2002) jetties were renovate for the PANAMAX type of the ships (capacity up to $65000 \mathrm{t}$ ), but today used for the POST PANAMAX (Fig. 1) and SUECMAX (Fig. 2) tankers with capacity up to $160000 \mathrm{t}$. POST PANAMAX and SUECMAX number of ships sailed up over the past 30 months (monthly) to Klaipeda oil terminal presented in the Fig. 3.

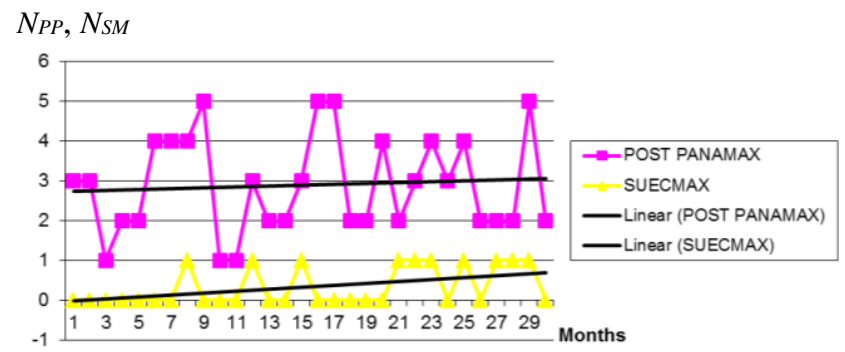

Fig. 3 POST PANAMAX and SUECMAX tankers sail to Klaipeda oil terminal in last 30 months

POST PANAMAX ships number $\left(N_{P P}\right)$ trend (liner forecast) is:

$$
N_{P P}=2,7+0,011 \cdot T ; R^{2}=0,006 .
$$
forecast) is:

SUECMAX ships number $\left(N_{S M}\right)$ trend (liner

$$
N_{S M}=0,05+0,05 \times T ; R^{2}=0,202 .
$$

Port quay walls used in many oil and bulk cargo terminals were constructed 30 or even more years ago and now are just adapted to new and bigger ships. During the last years construction, design and building regulations and standards of waterfront structures where improved and in many cases old standards and regulations imposed much higher safety requirements as are requested today $[1,2]$. Correct investigations and recalculations can assist to making right decisions, whether the quay walls safety parameters are sufficient for new type and bigger ships or it is necessary to take other actions, like temporary strengthening, renovation or approval of ship and hydro meteorological restrictions for the use of the concrete quay walls.

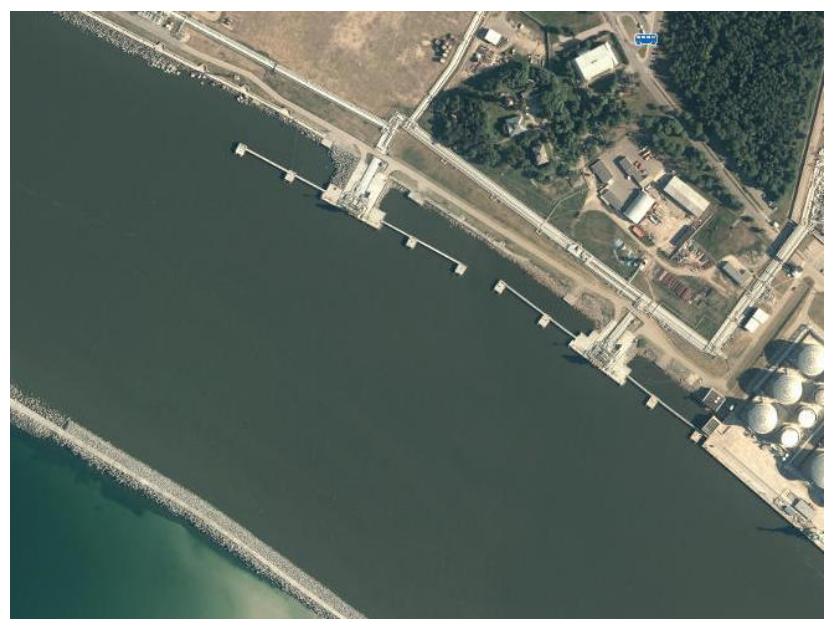

Fig. 4 Klaipeda port oil terminal and its jetties which has length $268 \mathrm{~m}$ each, depths near jetties up to $15,5 \mathrm{~m}$
As an example the East Baltic Sea ports like Klaipeda, Ventspils and others, in which oil terminals were always very busy and a change of the oil terminal and quay wall location is very complicate, could be taken. As example, in Fig. 4 are presented Klaipeda oil terminal jetties, which were built about 50 years ago, renovated 15 years ago, have length $268 \mathrm{~m}$ each and were oriented on PANAMAX type of tankers. Today are moored to this jetties POST PANAMAX (length about $250 \mathrm{~m}$ ) and SUECMAX tankers (length up to $290 \mathrm{~m}$ ).

To build new quay walls or jetties request a lot of investments, as well additional territory is need for the new waterfront constructions.

It is also very important to use optimal or minimum area as some ports are located very clause to the cities, which makes the spatial changes very complicated, therefore, optimization of land and water areas are major tasks to many such ports. It push ports use as maximum as possible existing waterfront constructions, adapted to new conditions.

\section{Quay wall strength and stability analysis, evaluation and optimization calculation methods}

Quay wall strength and stability standards or regulations and methods vary in different countries. For the investigation national standards or regulations could be used and it is very important to verify their compliance to international and national regulations like BS 6349: 2000, EAU 2012; STR 2.05.15 2004, etc. [1-3].

For example in Lithuania national waterfront structures design and construction regulations STR (construction technical regalements) are used which did not take enough into account dynamic loads, which are created by ships passing near ships moored to quay wall, i.e. hydrodynamic interaction, movement of a moored ship by the quay wall or jetty as a result of influence of periodical forces, which are created by wind gusts, waves, etc. As the main loads in the regulations are taken loads, which are created by ships on quay wall fenders during ship mooring operations, which are calculated by the formulas:

$$
E_{a b c}=f \frac{m^{\prime}(\Delta v)^{2}}{2},
$$

where $E_{a b c}$ - fender absorption energy; $m^{\prime}$ - the biggest calculated ship mass; $\Delta v$ - speed of ship contact with fender, which depends of ship displacement and mooring conditions and could be taken as shown in book [10]; $f$ - coefficient, which could be calculated as follows:

$$
f=f_{e} \times f_{s} \times f_{m} \times f_{c} \times f_{\text {tol }} \times f_{t},
$$

where $f_{e}$-eccentricity factor, in many cases for the sea ships could be taken as 0,$5 ; f_{s}$ - softness factor, for typical quay walls fenders could be taken as 0,9 ; for the hard material fenders like wood, this factor could be taken as 1,0; $f_{m}$ - add mass factor, could be used Vasco Costa results [9], for the ships with a block coefficient less than 0,75 , this factor is about $1,9-2,0$, for the ships, which have a block coefficient more than 0,75 , this factor is between $1,7-1,8$; $f_{c}$-compress factor, for close quay walls this factor could be taken as 1,0, for the jetties or open quay walls this fac- 
tor could be taken as 0,$9 ; f_{\text {tol }}$ - tolerance factor, for the calculations could be taken as 1,$1 ; f_{t}$-temperature influence factor, which depends on the average temperature in the region, in case of average temperature is +23 degrees Celsius, this factor is 1,0 , in case of lower than +23 degrees Celsius, this factor increases, for example for the South Baltic region, this factor is equal to 1,1 .

Additional loads on a ship moored to a quay wall are created by forces generated by wind, waves, current and other ships passing close to a moored ship (Fig. 5, Fig. 6).

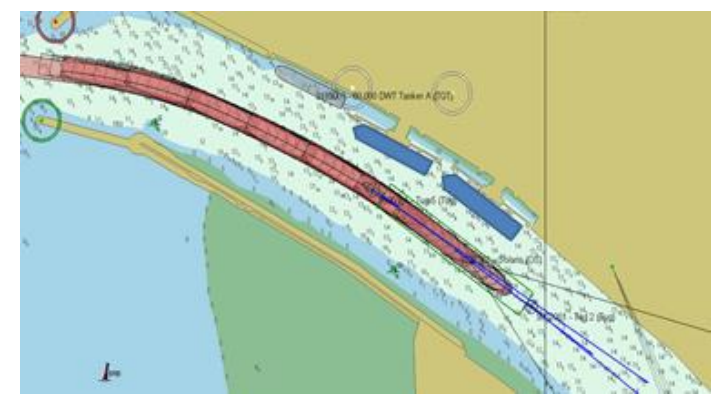

Fig. 5 Big ship passing clause to the moored to jetties ships (example) [14]

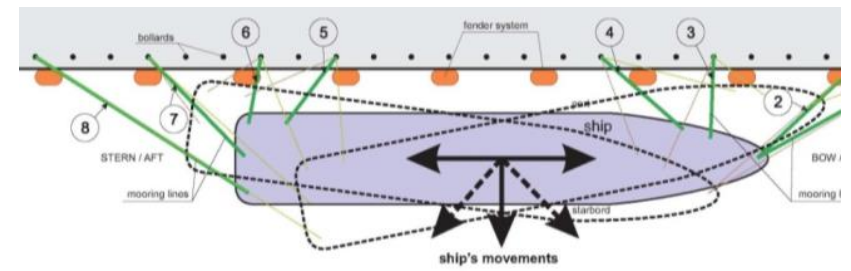

Fig. 6 Moored ship's movement near the quay wall as rezult of acting external forces

At the same time ships passing near a ship moored to a quay wall can create higher forces on the moored ship and quay walls due to wind, waves and current forces. A ship passing close to a moored ship creates hydrodynamic interaction forces which could be calculated by the method, presented in the article [15]. An example of the results of forces created by wind, current and waves on moored to jetty POST PANAMAX tanker and total forces, created by wind, current, ways and passing similar ship hydrodynamic interaction forces shown in Figs. 7-9.

Differences between the forces received, for example, by STR [3] and in case of added hydrodynamic interaction, could about $30 \%$ or even more depend on the passing ship dimensions, the speed and distance to a moored ship.

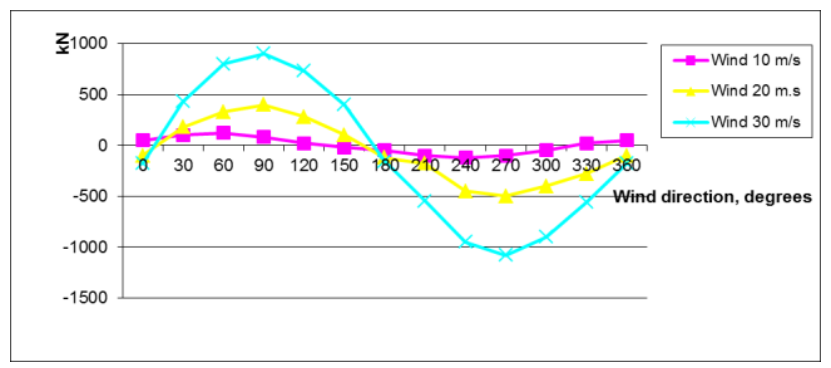

Fig. 7 On moored to jetty POST PANAMAX tanker acting lateral external forces: wind, current and waves (current and ways according wind velocity and direction), depending on wind velocity and direction

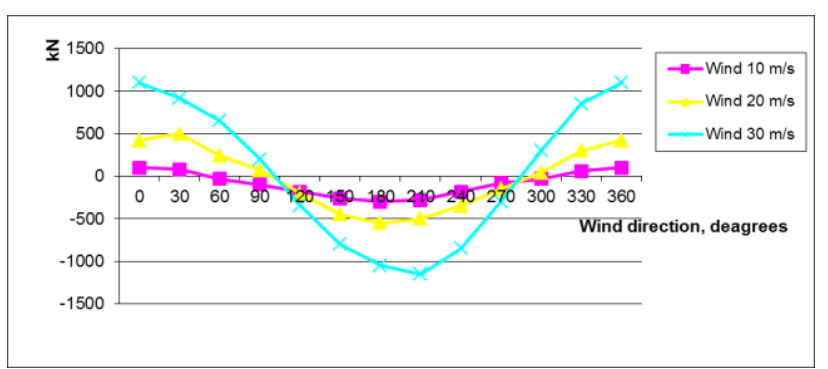

Fig. 8 On moored to jetty POST PANAMAX tanker acting a longitudinal external forces: wind, current and waves (current and ways according wind velocity and direction), depending on wind velocity and direction

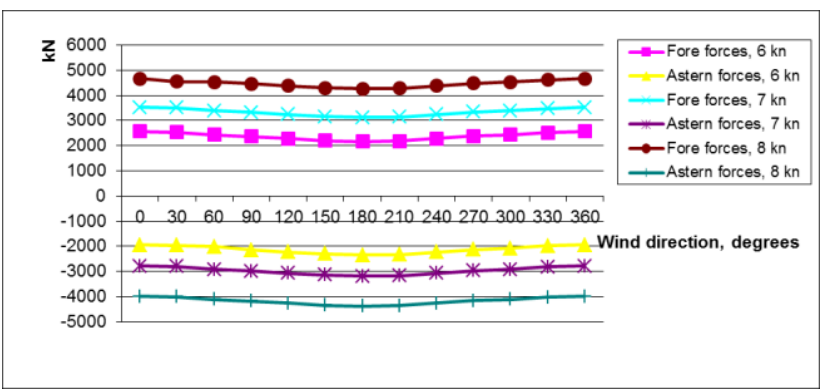

Fig. 9 Passing ships' hydrodynamic interaction and wind, waves and current forces on a POST PANAMAX type ship moored to a quay wall in case of passing same type of ship by different speed with a distance between ships about $40 \mathrm{~m}$ (speed 6, 7 and 8 knots) and forces created on mooring rope groups, received by the visual simulator "SimFlex Navigator" [14] and tested on a real moored ship

EAU 2012 and BS 6349: 2000 [1,2] partly take into account dynamic forces via safety coefficients, but at the same time the mentioned recommendations and standards do not take into account all possible maximum created forces, especially the hydrodynamic interaction forces between the ships. More accurate evaluation of the possible forces on the existing quay wall strength and stability could assist in making right decisions regarding safe exploitation and adaption of quay walls to the new shipping requirements.

Terminal and quay wall optimization in the ports interrelate with some main factors:

- maximizing the size of ships, which are planned to moor to the quay walls of the terminals;

- increasing terminals capacity, which is directly related to ship parameters;

- improvement of the port water areas close to the terminals and quay walls;

- improvement of the port navigational channels and ship turning basins.

The relation of the improvement of navigational channels and ship turning basins with ship size has been lately studded by many authors $[4,10]$. The navigational access of ships to the quay walls could be optimized on the basis of environmental conditions, such as current parameters, prevailing wind parameters, wave characteristics, depths and others. Quay wall optimization is very important in old ports, because in the past quay walls were built for smaller ships and now it is necessary to adapt them for bigger ones. 
Current influence on mooring and moored ships could be calculated as ship's movement on a "movement platform" (current) and it is very important that a "movement platform" has the minimal influence on other ships moored to a quay wall. An ideal condition to avoid the "movement platform" (current) influence possibility on other moored ships is a case when the current is parallel to the quay wall and on the access to a quay wall. In case of the current acting at some angle to the quay wall, the total ship movement speed could be calculated as follows:

$$
\sum \vec{v}=\vec{v}_{s}+\vec{v}_{c}
$$

where $\overrightarrow{v_{s}}-$ ship movement to a quay wall speed vector; $\overrightarrow{v_{c}}$ - current velocity vector.

At the same time $\sum \vec{v}$ must be acceptable regarding quay wall fender absorption energy which means:

$$
\sum \vec{v} \leq|\Delta v|
$$

where $\Delta v$-acceptable ship contact speed with a quay wall fender depends on ship displacement and mooring conditions and could be taken as shown in book [10] or could be calculated as follows:

$$
\Delta v=\sqrt{\frac{2 E_{a b s}}{m^{\prime}}},
$$

where $m^{\prime}$ - ship mass; $E_{a b c}$ - fenders' absorption energy, calculated by Eqs. (3) and (4).

At the same time in case of influence of wind, current as well as ship maneuvering facilities, such as thrusters, rudders, propellers or tugs, the total possible force in case of movement to a quay wall, acting forces could be expressed as follows:

$$
R_{y i n}+P_{y}+R_{y}+R_{a y}+R_{c y}+N_{y}+T_{y}+T_{T}=0,
$$

where $R_{\text {yin }}$ - inertial force, which could be calculated as follows:

$$
R_{y i n}=m^{\prime} a,
$$

where $a$-acceleration, which could be calculated as follows:

$$
a=\frac{v_{1}^{\prime}-\Delta v}{2},
$$

where $v_{1}^{\prime}$ - maximum possible ship's speed before movement to a quay wall, in practice it is not more than 2 knots $(1,0 \mathrm{~m} / \mathrm{s})$.

$P_{y}$ - rudder power, which could be rich during maneuvers near quay wall and could be calculated as follows:

$$
P_{y}=C_{y} \frac{\rho}{2} S_{P} v_{P}^{2},
$$

where $C_{y}$ - rudder hydrodynamic coefficient, during maneuvers near quay walls big rudder angles are used and this coefficient could be taken about 1,$0 ; \rho$-water density; $S_{p}$ - ruder square, which is in ship's propeller screw, can be calculated as follows:

$$
S_{P}=D_{P} b_{P}
$$

where $D_{P}$ - diameter of the ship's propeller; $b_{P}$ - width of the ship rudder.

$v_{P}$ - ship propeller screw speed, could be calculated as follows [2] (EAU 2012):

$$
v_{P}=0,95 n_{P} D_{P},
$$

where $n_{P}$ - propellers revolutions, $\mathrm{s}^{-1}$.

$R_{y}$ - force created by the ship hull on Y direction, could be calculated as follows [10]:

$$
R_{y}=C_{R y} \frac{\rho}{2} L T\left(v+v_{c}\right)^{2},
$$

where $C_{R y}$-hydrodynamic coefficient when ship hull is taken as "wing", for the practical calculations, because the angle between ship hull and current is low (usually not more than $10^{\circ}-15^{\circ}$ ), could be taken about $0,1-0,2$; $L$ - ship length between perpendiculars; $T$-average ship draft; $v$ - ship movement speed, in many cases before contact with quay wall this speed is equal to $0,10-0,15 \mathrm{~m} / \mathrm{s}$; $v_{c}$ - current velocity. ed as follows:

$R_{a y}$ - aerodynamic force, which could be calculat-

$$
R_{a y}=C_{a y} \frac{\rho_{1}}{2} S_{x} v_{a}^{2} \sin q_{a}
$$

where $C_{a y}$-aerodynamic coefficient, which is in average about 1,07-1,30 (specific data could be taken from aerodynamic tube testing's); $\rho_{1}$ - air density, for the calculations could be taken as $1,25 \mathrm{~kg} / \mathrm{m}^{3} ; S_{x}$ - ship air projection on middle square; $v_{a}$ - wind velocity; $q_{a}$ - wind course angle (angle to a quay wall in ship's contact with quay wall fender moment).

$R_{c y}$ - current created force, which could be calculated as follows:

$$
R_{c y}=C_{y}^{\prime} \sin q_{c} \frac{\rho}{2} L T v_{c}^{2},
$$

where $C_{y}^{\prime}$-hydrodynamic coefficient of the ship hull and its dependence on the current angle to the quay wall and could be calculated as follows:

$$
C_{y}^{\prime}=0,8 \sin q_{c},
$$

where $q_{c}$ - current angle to a quay wall; $v_{c}$ - current velocity.

$N_{y}$ - force created by thrusters, could be taken from ship thruster specification, or calculate as follows:

$$
N_{y}=K_{1}^{\prime} \rho n_{N}^{2} D_{N}^{4}\left(1-t^{\prime \prime}\right),
$$


where $K_{1}^{\prime}$ - propeller's coefficient, in case of low ship's speed for calculations could be taken as 0,$2 ; n_{N}$ - thruster's propeller revolutions, $\mathrm{s}^{-1} ; D_{N}$ - thruster's propeller diameter; $t^{\prime \prime}$ - thruster's propeller propulsion coefficient, in case of low ship's speed for calculations could be taken as 0,2 .

$T_{y}$-ship propellers perpendicular created force, could be not taken in account during mooring operations when a ship is close to a quay wall, but this force should be taken into account during ship stopping and other cases and can be expressed as follows:

$$
T_{y}=K_{1}^{\prime} \rho n_{T}^{2} D_{P}^{4}\left(1-t^{\prime \prime}\right) \sin \alpha_{s},
$$

where $n_{T}$ - ship's propeller revolutions, $\mathrm{s}^{-1} ; \alpha_{s}$ - ship's propeller screw angle for calculations could be taken as 3 degrees.

$T_{T}$ - tug created force, which depends on tug characteristics and work methods [13] and can be expressed as follows:

$$
T_{T}=K_{1}^{\prime} \rho n_{T D}^{2} D_{T D}^{4}\left(1-t^{\prime \prime}\right) \cos \beta-C_{T} \frac{\rho}{2} S_{T} v_{T}^{2},
$$

where $n_{T D}$-tug's propeller revolutions, $\mathrm{s}^{-1} ; D_{T D}$-tug's propeller diameter; $\beta$ - tug's rope vertical angle; $C_{T}$ - tug's hull hydrodynamic resistance coefficient; $S_{T}$ - tug's hull square in water; $v_{T}$ - tug speed.

In many practical cases it is very important to consider possible tug influence on a ship during the mooring operation and how it can influence the total forces or moored ship contact speed with fenders and finally influence a quay wall stability and strength. Situations with tugs are important in case of tug operation delays, especially decreasing ship movement speed before a mooring ship contact with quay wall fenders. Correct following of tug commands could increase or decrease forces by which a mooring ship impacts a quay wall.

\section{Case study of a real quay wall situation}

As a case study one of the dolphin of the quay wall No. 1 in Klaipeda port was taken and maximum possible forces, which impact a quay wall in case of a moored to a quay wall POST PANAMAX tanker and a passing POST PANAMAX tanker, which create hydrodynamic interaction, as well as influence of different wind directions, speed and current on the moored ship, were calculated. The calculated forces presented in Figs. 10 and 11, depend on the wind velocity and the directions and the passing of the above mentioned POST PANAMAX tanker with the speed of 7 knots at a $30 \mathrm{~m}$ distance between the ships.

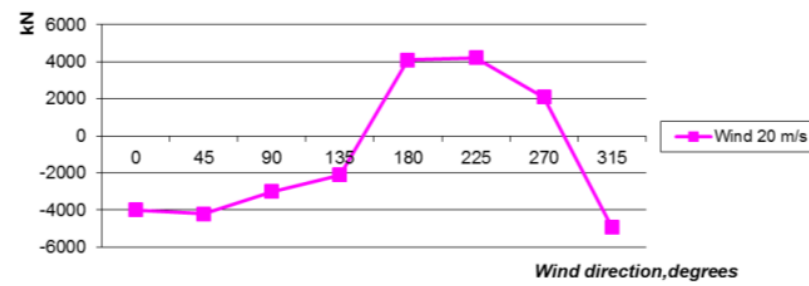

Fig. 10 Total forces acting on a quay wall by the moored POST PANAMAX tanker with the hydrodynamic interaction of the POST PANAMAX tanker passing at 7 knot speed, the current up to 4 knots parallel to a quay wall and wind $20 \mathrm{~m} / \mathrm{s}$ from different

\section{directions}

Calculations and testing by simulator and real moored ships experimental data, received by laser system "DOCKMASTER - 3" [16], which is implemented on studded quay walls were made. Calculation and simulation boundaries were taken up wind velocity (30 s average wind) $20 \mathrm{~m} / \mathrm{s}$ and current parallel to quay wall up to 4 knots, because until mentioned wind velocity POST PANAMAX tankers keep moored to the quay wall. Additionally calculations and simulations were made by similar ship pass on different distances up to $30 \mathrm{~m}$ in mentioned hydro meteorological and hydrological conditions.

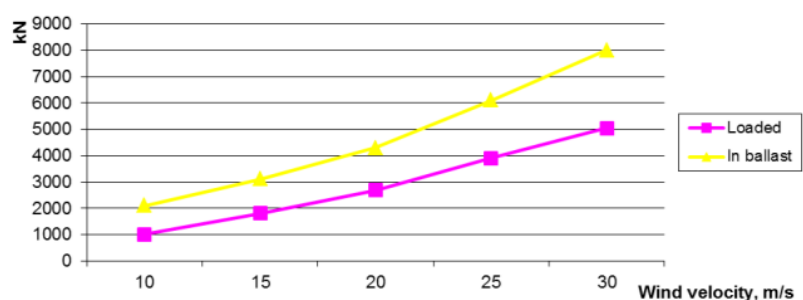

Fig. 11 The moored POST PANAMAX tanker created maximum forces in ballast and loaded on a quay wall in case of another POST PANAMAX tanker passing at a $30 \mathrm{~m}$ distance from a moored ship at 7 knot speed as hydrodynamic interaction on the moored ship. Wind velocity up to $30 \mathrm{~m} / \mathrm{s}$ perpendicular to quay wall, current direction parallel to the quay wall (speed 4 knots)

For the selected dolphin strength and stability calculations were made using a special calculation program STAAD Pro 2004 [17] for the evaluation of quay wall strength and stability, in which were given profiles of the quay wall dolphins, shown on Figs. 12 and 13. Evaluation was made taking into account the construction and profiles of the dolphin, which has corrosion up to $30 \%$.

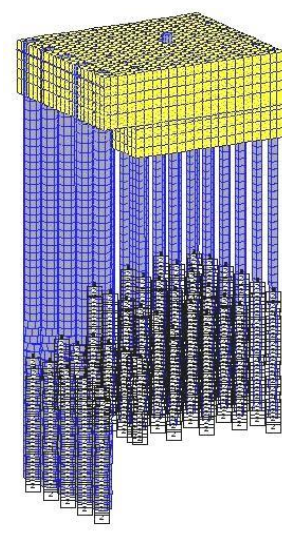

Fig. 12 Dolphin construction
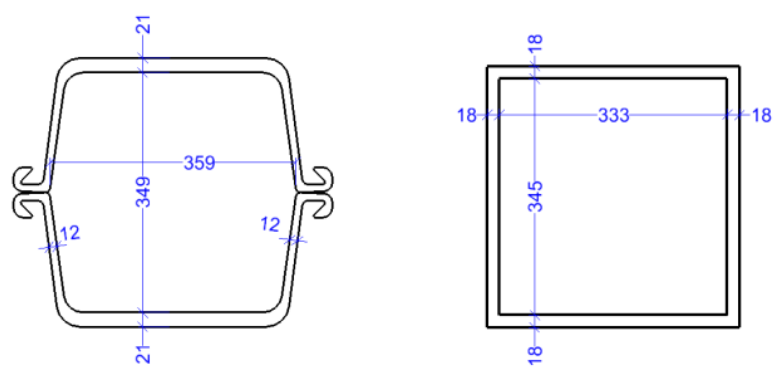

Fig. 13 Dolphin profiles (real on left and used for the 
calculation on right)

On basis of the method, presented above in section 3, strength and stability of the selected quay dolphin were evaluated. Forces acting on the selected dolphin were taken in case mooring to quay wall POST PANAMAX tanker and possible influence on dolphin other external forces.

Calculation and simulation results were received by the mentioned program STAAD Pro 2004 [17], as example, presented on Fig. 14 (dolphin's deformation) and on Fig. 15 (dolphin bending moments). Received values of the dolphin deformations and bending moments of the dolphin are presented in Table.

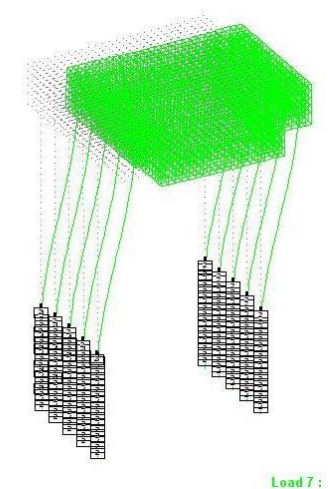

Fig. 14 Dolphin deformation, as example, received by program STAAD Pro 2004

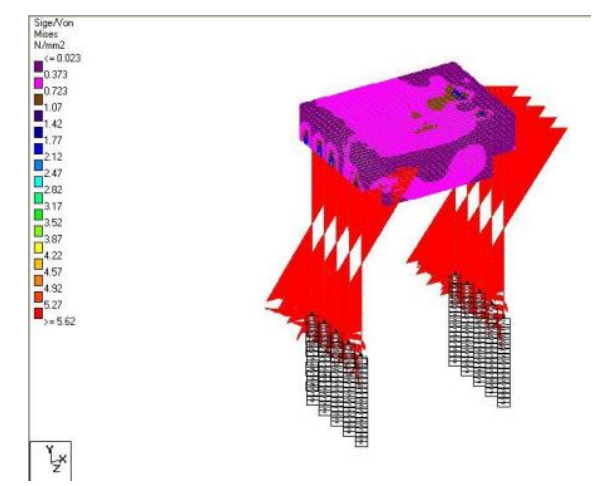

Fig. 15 Dolphin bending moments as example, received by program STAAD Pro 2004

Table

Dolphin's bending moments and deformations depends on acting total forces on dolphin (STAAD Pro 2004 [17])

\begin{tabular}{|l|c|c|c|c|c|}
\hline $\begin{array}{c}\text { Total forces, } \\
\mathrm{kN}\end{array}$ & 2000 & 4000 & 6000 & 8000 & 10000 \\
\hline $\begin{array}{l}\text { Bending mo- } \\
\text { ments, kNm }\end{array}$ & 15 & 40 & 68 & 89 & 96 \\
\hline $\begin{array}{l}\text { Deformation, } \\
\mathrm{mm}\end{array}$ & 5 & 8 & 14 & 20 & 29 \\
\hline
\end{tabular}

For the simulation by STAAD Pro 2004 [17], were taken acting forces and forces directions, received by methodic presented in section 3 of the paper and checked on real ships during mooring operations by laser system "DOCKMASTER - 3" . Simulation and testing boundary conditions were taken similar to the real ship's mooring condition that means hydro meteoroidal and hydrological conditions (wind velocity up to $15 \mathrm{~m} / \mathrm{s}$, current up to 4 knots) and ship's contact speed with quay wall fenders.

Maximum dolphin's deformations were received on Y direction (perpendicular to quay wall line). In simulation program STAD Pro 2004, bending moments expressed as $\mathrm{kNm}$, and in table 1 , were presented bending moments results depends of the acting forces as $\mathrm{kN}$.

Were calculated possible maximum deformations of the dolphin according existing different regulations, standards and recommendations. Maximum deformation according recommendations and standards [2, 3, 5] for the studded dolphin can reach up to $32 \mathrm{~mm}$. On basis calculations and simulations were prepared practical graphs (Figs. 11 and 16) for the control possible maximum forces and deformations of the studded quay dolphin for the POST PANAMAX tanker depend of hydro meteorological and hydrological conditions.

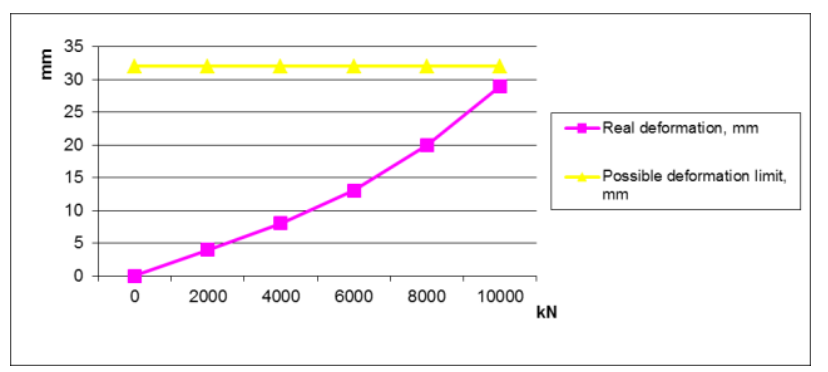

Fig. 16 Dolphin deformation in Y direction depends on the forces, presented on Fig. 8

The calculation results show, that the studied dolphin could be used for mooring the PANAMAX type tankers in all conditions, because deformations and bending moments are less then requested by the local (Lithuanian) regulations.

\section{Conclusions}

New realities in ports request correct evaluation of the quay walls that will be possible avoid accidents.

Standards and recommendations in different countries regarding waterfront structures have differences and it is necessary take in account for the waterfront structures evaluation.

Methodic presented in this paper can be used for the quay walls evaluation and decisions extend live time or change possible mooring ship's parameters.

Received calculation and testing strength and stability results for the selected quay dolphin were checked by real POST PAMAMAX ships during mooring operations.

Prepared possible acting on selected dolphin forces and dolphin deformations depend of the mooring conditions and possible could be used for the practical tasks.

\section{References}

1. British Standard BS - 6349: 2000.

2. EAU 2012: Recommendations of the Committee for Waterfront Structures - Harbours and Waterways. 2012. Ernst \& Sohn. Berlin.

3. STR 2.05.15:2004 Hydraulic Structures effects and loads. 2004. Vilnius (In Lithuanian)

4. Wijffels, J.; Paulauskas, V. 2010. Ships with big free- 
board safety in ports, PIANC Conference, Liverpool, 2010, presentation No. 55.

5. Flory, J.F.; Ractliffe, A. 1994. Mooring arrangement management by computer, Ship Operations, Management and Economics Symposium, SNAME, Jersey City, NY.

6. Glogal Marine traffic Intelligence / AIS Marine Traffic https://www.google.lt/?gws_rd=ssl\#q=marine+traffic. 2016.09.002.

7. Choudhury, D.; Ahmad, S.M. 2008. Stability of waterfront retaining wall subjected to pseudo-dynamic earthquake forces, Journal of Waterway, Port, Coastal and Ocean Engineering 134(4): 252-260. http://dx.doi.org/10.1061/(ASCE)0733950X(2008)134:4(252).

8. Čižas, A. 1993. Materials. Structural elements of mechanics. Vilnius: Technika. (In Lithuanian)

9. Wolters, H.J. 2012. Reliability of Quay walls, MSc thesis on probabilistic Finite Element calculations of quay walls, Delft University of Technology.

10. Farzaneh, O.; Askari, F.; Ganjian, N. 2008. Three dimensional stability analyses of convex slopes in plain view, ASCE, Journal of Geotechnical and Geoenvironmental Engineering 134(8): 1192-1200. http://dx.doi.org/10.1061/(ASCE)10900241(2008)134:8(1192).

11.Shiau, J.S.; Merifield, R.S.; Lyamin, A.V.; Sloan, S.W. 2011. Undrained stability of footings on slopes, ASCE, International Journal of Geomechanics 11(5): 381-390.

http://dx.doi.org/10.1061/(ASCE)GM.19435622.0000092.

12. Belevičius, R.; Šešok, D.; Kačeniauskas; A.; Mockus, J. 2010. Application of GRID computing for optimization of grillages, Mechanika 2(82): 63-69.

13. Paulauskas, V. 2013. Ships Entering the Port, N.I.M.S., Riga.

14. SimFlex Navigator Simulator. 2014. Force Technology, Denmark.
15. Paulauskas, V.; Paulauskas, D.; Maksimavicius, R.; Jonkus, M. 2014. Hydrodynamic interactions between ships in narrow channels, Transport 29(2): 212-216. http://dx.doi.org/10.3846/16484142.2014.931886.

16. Laser system "DOCKMASTER - 3". 2002. Marimatech, Denmark.

17. STAAD Pro 2004 calculation program (STAAD 2004).

V. Paulauskas, D. Paulauskas, B. Placiene,

R. Barzdziukas

\section{QUAY WALL STABILITY AND STRENGTH EVALUATION}

S u m m a r y

In some ports terminals were created 40 or even more years ago and until now work very intensively. During a long time exploitation of the quay walls, their stability and strength decrease and it is necessary to replace the existing quay walls: to renovate them or build new ones, however, there are some space or investments limitations, delayed decisions of renovation or building possibilities without decreasing capacity and productivity of the terminals.

The article discusses possibilities of evaluation the stability and strength of the quay walls or replacing some of them with the minimum disturbance of the terminal activity; as well as the methodology of the evaluation, which can assist to increase or optimize technical parameters and capacity of the port quay walls.

Key words: quay wall; quay wall strength; quay wall stability; quay wall evaluation.

Received December 04, 2015 Accepted April 14, 2017 